\title{
Biological and Serological Properties of Potato virus $Y$ Isolates in Northeastern United States Potato
}

P. M. Baldauf, Department of Plant Pathology, Cornell University, Ithaca, NY 14853; S. M. Gray, Department of Plant Pathology, Cornell University, and United States Department of Agriculture-Agricultural Research Service (USDA-ARS), Plant Protection Research Unit (PPRU), Ithaca, NY 14853; and K. L. Perry, Department of Plant Pathology, Cornell University, Ithaca, NY 14853

\begin{abstract}
Baldauf, P. M., Gray, S. M., and Perry, K. L. 2006. Biological and serological properties of Potato virus $Y$ isolates in northeastern United States potato. Plant Dis. 90:559-566.

A survey of six potato viruses, Potato virus A (PVA), Potato virus $M$ (PVM), Potato virus $S$ (PVS), Potato virus X (PVX), Potato virus $Y$ (PVY), and Potato leafroll virus (PLRV), was conducted in New York and Maine during 2002 and 2003. Leaf samples were tested by enzymelinked immunosorbent assay and PVY-positive samples were further tested to determine whether a necrotic strain of PVY $\left(\mathrm{PVY}^{\mathrm{N}}\right)$ or a strain able to induce necrosis in tobacco and in potato tubers (PVYNTN) were present. In both years, PVY and PVS were identified in a majority of the samples, and mixed infections predominated in $83 \%$ of the symptomatic leaves in 2002. Of the total 394 PVY-positive samples, 3 reacted with monoclonal antibody (MAb) 1F5 and caused veinal necrosis $(\mathrm{VN})$ in tobacco. Two of these isolates caused tuber necrosis in the potato $\mathrm{cv}$. Yukon Gold. Three PVY isolates reacted with MAb 1F5 but did not cause VN in tobacco, and two caused VN but did not react with MAb 1F5. None of these eight isolates were able to overcome the Ry resistance gene in the potato cultivar Eva, but several were able to overcome the $N y$ resistance gene found in Allegany. PVYN isolates were not widespread in the northeastern United States; however, several PVY isolates differed from both PVY ${ }^{\mathrm{N}}$ and the ordinary strain of PVY and may represent strain recombinants.
\end{abstract}

There are 36 viruses in several different genera that are known to infect potato in agricultural settings (41). Potato virus $A$ (PVA) and Potato virus $Y$ (PVY) (genus Potyvirus), Potato virus $M$ (PVM) and Potato virus $S$ (PVS) (genus Carlavirus), Potato virus $X$ (PVX) (genus Potexvirus), and Potato leafroll virus (PLRV) (genus Polerovirus) are common in North America, although their prevalence has been reduced greatly through effective seed certification programs (10). Recently, PVY has re-emerged as a problem due to changes in cultivar selection and the introduction and spread of necrotic strains of PVY $(23,26)$

PVY is the type member of the genus Potyvirus, having a monopartite positivesense single-stranded RNA genome of approximately $10 \mathrm{~kb}$ (22). The ordinary or common strain of PVY $\left(\mathrm{PVY}^{\mathrm{O}}\right)$ generally causes observable mosaic symptoms and stunting in most potato cultivars $(5,20)$. $\mathrm{PVY}^{\mathrm{O}}$ incidence has been minimized by

Corresponding author: K. L. Perry

E-mail: klp3@cornell.edu

Accepted for publication 29 November 2005.

DOI: 10.1094/PD-90-0559

This article is in the public domain and not copyrightable. It may be freely reprinted with customary crediting of the source. The American Phytopathological Society, 2006. seed certification programs and has not been considered to be a major impediment to potato production, although widespread acceptance of cultivars that are asymptomatic to $P V Y^{\mathrm{O}}$ infection has contributed in increased PVY incidence in recent years. The necrotic strain of PVY $\left(\mathrm{PVY}^{\mathrm{N}}\right)$ is defined by its ability to cause a lethal veinal necrosis in tobacco (28). Some isolates of $\mathrm{PVY}^{\mathrm{N}}$ also are able to induce necrotic ringspot symptoms in potato tubers (21), greatly decreasing quality and marketability. The latter isolates are designated $\mathrm{PVY}^{\mathrm{NTN}}(\mathrm{NTN}=$ necrosis in tobacco and tuber necrosis in potato). Some PVYNTN isolates are recombinants between $\mathrm{PVY}^{\mathrm{O}}$ and PVY $^{\mathrm{N}}$ strains $(2,15)$, whereas others have arisen by point mutations (31). Recombinant strains designated as PVYWilga (6) or $\mathrm{PVY}^{\mathrm{N}: \mathrm{O}}$ (30) induce veinal necrosis in tobacco, similar to $\mathrm{PVY}^{\mathrm{N}}$ strains, but are serologically related to $\mathrm{PVY}^{\mathrm{O}}(6,25)$. These PVY ${ }^{\mathrm{N}: \mathrm{O}}$ strains are becoming more prevalent in potato grown in the United States and Canada (39). Monoclonal antibodies (MAbs) have been developed in an attempt to differentiate $\mathrm{PVY}^{\mathrm{O}}, \mathrm{PVY}^{\mathrm{N}}$, and the stipple-streak strain $\operatorname{PVY}^{\mathrm{C}}(10)$.

PVY strains are differentiated by the use of biological assays on Solanaceous plant species $(17,19)$ and by nucleic acid-based and serological techniques $(39,40,45)$. Differential potato genotypes have been used to distinguish PVY strains based on symptomatology and the ability of strains to overcome resistance genes (19). There are two prominently described forms of PVY resistance in potato: extreme resistance derived from $R y$ genes and hypersensitive resistance derived from $N y$ genes (42). Extreme resistance is manifested as very low to undetectable viral replication and is effective against all known PVY isolates (48), whereas hypersensitive resistance is strain dependent and is manifested as a localized or systemic necrosis $(4,47)$.

Surveys of PVY have been conducted in major potato growing regions of North America (23), but these have not included potato grown in the northeastern United States. Roughly $80 \%$ of the potato acreage in the northeastern United States is located in New York and Maine (1). Potato crops from this region account for approximately $8 \%$ of the total potato acreage in the United States, and production is estimated to be worth over $\$ 200$ million (1). It is important to have an understanding of the diversity of PVY strains present in the northeastern United States in order to guide disease management practices and cropping strategies.

This study describes a potato virus survey conducted in the northeastern United States in 2002 and 2003. The goals were to determine the prevalence of six potato viruses in plants with virus symptoms and to evaluate the diversity of strains of PVY in this part of the United States. Several PVY isolates that differ from the common $\mathrm{PVY}^{\mathrm{O}}$ strain are described (i.e., those isolates that cause veinal necrosis in tobacco, are recognized by MAb $1 F 5$, or induce tuber necrosis in the potato $\mathrm{cv}$. Yukon Gold). This is the first report of necrotic or tuber necrotic strains of PVY $\left(\mathrm{PVY}^{\mathrm{N}}\right.$ and $\mathrm{PVY}^{\mathrm{NTN}}$ ) and of potential PVY recombinants (PVY-Wilga or $\mathrm{PVY}^{\mathrm{N}: \mathrm{O}}$ ) in potato grown in the northeastern United States.

\section{MATERIALS AND METHODS}

Field collections. In June through $\mathrm{Au}-$ gust 2002, potato leaves were collected from fields in Steuben, Tompkins, and Wyoming Counties in New York state and in Aroostook County, Maine. Potato fields were scouted by dividing fields into five sections and walking a transect of the field four times. Leaf tissue from plants expressing virus-like symptoms was collected. Symptoms included necrotic le- 
sions, leaf mosaic, leaf mottling, rugosity, stunting, or discoloration. Tissue from plants with PLRV-like symptoms (prominent rolling of leaves and stiff upright habit of plants) was not collected. In June through August 2003, collections were made in the same counties as in 2002, and additional fields were sampled in Allegany, Cayuga, Essex, Franklin, Genesee, Livingston, Ontario, Orleans, Seneca, Suffolk, and Wayne Counties in New York state. In an attempt to detect asymptomatic or mildly symptomatic isolates of PVY, 10 asymptomatic plants were collected randomly from each cultivar or breeding line in each field visited in 2003.

Potato virus detection. Samples from New York and Maine were tested for PVA, PVM, PVS, PVX, PVY, and PLRV by double-antibody sandwich enzyme-linked immunosorbent assays (DAS-ELISA; 7) using commercial antibodies, primarily polyclonal (Agdia Inc., Elkhart, IN). Absorbance values three times greater than the average of uninfected greenhousegrown potato plant controls were considered positive unless the average uninfected control value was below 0.030 , in which case a value of 0.100 and above was considered positive. In 2002, the leaf tissue remaining from samples that tested positive for PVY was lyophilized, stored at $-20^{\circ} \mathrm{C}$, and subsequently tested using differential hosts and a $\mathrm{PVY}^{\mathrm{N}}$ triple-antibody sandwich (TAS)-ELISA (11). Briefly, microtiter plates were coated with anti-PVY polyclonal antibody. The wells were rinsed with phosphate-buffered saline (PBS; $0.05 \%$ Tween 20) between this and each subsequent step. Lyophilized tissue in powder form at $0.025 \mathrm{~g} / \mathrm{ml}$ of PBS $(\mathrm{pH}$ 7.4) was vortexed vigorously, and $100 \mu \mathrm{l}$ was added to duplicate wells. The PVY ${ }^{\mathrm{N}}$ MAb 1F5 (11) was diluted in conjugate buffer (1:5000) and $100 \mu \mathrm{l}$ was added to the wells. Next, $100 \mu \mathrm{l}$ of alkaline phosphatase conjugated anti-mouse goat antibody (Sigma-Aldrich, Milwaukee, WI) diluted (1:5000) in conjugate buffer was added to wells. In 2003, the samples testing positive for PVY were tested immediately for recognition by MAb 1F5 by TASELISA, using potato sap diluted in PBS $(1: 10)$ as the source of antigen. The 10 asymptomatic plant samples randomly collected in each field visited were tested as a single composite sample. To assist in the identification of mixed infections or potential recombinant isolates that possess a $\mathrm{PVY}^{\mathrm{O}}$ and $\mathrm{PVY}^{\mathrm{C}}$-associated antigen and tobacco veinal necrosis determinants, $\mathrm{PVY}^{\mathrm{N}}$ isolates also were tested by TASELISA using MAb 2, which recognizes an antigen common to most $\mathrm{PVY}^{\mathrm{O}}$ and $\mathrm{PVY} \mathrm{Y}^{\mathrm{C}}$ isolates (11).

Bioassays to differentiate PVY strains. The diluted sap used in the ELISAs from the PVY-positive samples was used to mechanically inoculate Carborundum-dusted tobacco (Nicotiana tabacum cv. White Burley). Tobacco plants were monitored for symptoms weekly and symptoms were recorded 21 days post inoculation (dpi) as veinal necrosis, mottle mosaic, or none. To further characterize isolates that induced veinal necrosis in tobacco or reacted with the MAb 1F5, the isolates were inoculated mechanically onto a set of Carborundum-dusted greenhousegrown differential potato genotypes, including Solanum tuberosum cvs. Atlantic, Allegany, Eva, and a clone from the New York potato breeding program designated NY115. Additionally, the indicator host $S$. brachycarpum was used because it was reported to express a necrotic response when inoculated with $\mathrm{PVY}^{\mathrm{N}}$ and mosaic symptoms when inoculated with $\mathrm{PVY}^{\mathrm{O}}$ (38). Allegany possesses the hypersensitivity gene $N y$ (49); it expresses local lesions when inoculated mechanically with $\mathrm{PVY}^{\mathrm{O}}$, and a $\mathrm{PVY}^{\mathrm{N}}$ isolate was reported to establish an asymptomatic infection (49). Eva possesses the extreme resistance gene $R y_{\text {adg }}$ (derived from $S$. tuberosum subsp. andigena; 36) that has conferred resistance to all tested PVY strains. Atlantic and NY115 do not have

Table 1. Number of individual symptomatic and composite asymptomatic samples testing positive for Potato virus A (PVA), Potato virus M (PVM), Potato virus S (PVS), Potato virus X (PVX), Potato virus $Y$ (PVY), or Potato leafroll virus (PLRV) as determined by double-antibody sandwich enzymelinked immunosorbent assay

\begin{tabular}{|c|c|c|c|}
\hline \multirow[b]{2}{*}{ Virus detected } & \multicolumn{2}{|c|}{ Symptomatic samples ${ }^{a}$} & \multirow{2}{*}{$\begin{array}{c}\text { Asymptomatic samples } \\
2003\end{array}$} \\
\hline & 2002 & 2003 & \\
\hline PVY & 182 & 203 & 9 \\
\hline PVS & 173 & 155 & 48 \\
\hline PVX & 55 & 27 & 7 \\
\hline PVM & 36 & 0 & 0 \\
\hline PVA & 12 & 1 & 0 \\
\hline PLRV & 1 & 2 & 0 \\
\hline No virus detected & 4 & 76 & 41 \\
\hline Total samples tested & 205 & 300 & 103 \\
\hline
\end{tabular}

a Virus symptoms included necrotic lesions, leaf mosaic, leaf mottling, rugosity, stunting, and discoloration.

${ }^{\mathrm{b}}$ Composite samples consisted of 10 leaves, each from a different asymptomatic plant.

${ }^{c}$ Due to mixed infections, the sum of samples testing positive for each virus does not equal the total number of samples tested.

any known resistance to PVY and served as susceptible controls.

Two plants of each potato genotype were inoculated mechanically with each PVY reference and field-collected isolate that induced tobacco veinal necrosis, reacted with MAb 1F5, or both. S. tuberosum cultivars were grown from sprouted foundation seed and inoculated 2 to 3 weeks post emergence. S. brachycarpum plants were grown from virus-free in vitro plantlets and inoculated when 25 to $30 \mathrm{~cm}$ tall. Reference isolates included $\mathrm{PVY}^{\mathrm{O}}$ (46), several PVY ${ }^{\mathrm{N}}$ isolates (8), and the stipple-streak strain PVYC (46). Plants were monitored for symptoms on inoculated leaves at 8 to $12 \mathrm{dpi}$ and on systemic leaves at 21 to $28 \mathrm{dpi}$. Systemic leaves also were tested for PVY by DAS-ELISA 21 dpi. The experiment was repeated twice.

To determine whether the $\mathrm{PVY}^{\mathrm{N}}$ isolates induced tuber necrosis, greenhouse-grown plants of the $S$. tuberosum cv. Yukon Gold were inoculated mechanically 2 to 4 weeks post emergence (four to eight fully expanded leaves) and grown to maturity in 3.7-liter (1-gal) plastic pots. Upper uninoculated leaves were tested by DASELISA 2 to 4 weeks post inoculation and tubers from systemically infected plants were observed for tuber necrosis symptoms at harvest and after 4 weeks of storage at $4^{\circ} \mathrm{C}$. These experiments were repeated at least three times (except for AL2) during the course of a year, inoculating four or more plants with each isolate per experiment.

Table 2. Percent of total single and mixed infections of Potato virus A (PVA), Potato virus $M$ (PVM), Potato virus $S$ (PVS), Potato virus $X$ (PVX), Potato virus $Y$ (PVY), and Potato leafroll virus (PLRV) detected in symptomatic samples

\begin{tabular}{lcc}
\hline & \multicolumn{2}{c}{ Infected (\%) } \\
\cline { 2 - 3 } Infections & $\mathbf{2 0 0 2}$ & $\mathbf{2 0 0 3}$ \\
\hline Single & & \\
PVY & 11 & 32 \\
PVS & 4 & 9 \\
PLRV & $\ldots$ & 0.3 \\
No virus detected & 2 & 25 \\
Mixed & & \\
PVS, PVY & 42 & 27 \\
PVS, PVX, PVY & 16 & 5 \\
PVM, PVS, PVY & 11 & $\ldots$ \\
PVM, PVS, PVX, PVY & 3 & $\ldots$ \\
PVS, PVX & 2 & $\ldots$ \\
PVX, PVY & 2 & 1 \\
PVA, PVS & 1 & $\ldots$ \\
PVA, PVM, PVS & 1 & $\ldots$ \\
PVA, PVS, PVX, PVY & 1 & $\ldots$ \\
PVM, PVS & 0.5 & $\ldots$ \\
PVM, PVX, PVY & 0.5 & $\ldots$ \\
PVA, PVS, PVX & 0.5 & $\ldots$ \\
PVA, PVS, PVY & 0.5 & 0.3 \\
PVA, PVX, PVY & 0.5 & $\ldots$ \\
PVA, PVM, PVS, PVX & 0.5 & $\ldots$ \\
PVA, PVM, PVS, PVY & 0.5 & $\ldots$ \\
PVS, PVX, PVY, PLRV & 0.5 & $\ldots$ \\
PVA, PVM, PVS, PVX, PVY & 0.5 & $\ldots$ \\
PVS, PLRV & $\ldots$ & 0.3 \\
\hline & & \\
\hline
\end{tabular}




\section{RESULTS}

Field surveys. All six viruses were detected in the 2002 survey, with five of the viruses detected in 2003 (Table 1). In the symptomatic samples, PVY and PVS were detected in more than half of the total number of samples in both years. PVX was found in 27 and $9 \%$ of the samples in 2002 and 2003, respectively. PVM was detected in $18 \%$ of the samples tested in 2002 , but was not detected in 2003. PVA was detected in 6 and $0.3 \%$ of the symptomatic samples collected in 2002 and 2003, respectively. Consistent with the biased sampling emphasizing mosaic symptoms, PLRV was detected in only 0.5 to $1 \%$ of the symptomatic samples collected (Table 1). In the asymptomatic composite samples, PVS, PVY, and PVX were detected in 47,9 , and $7 \%$ of the samples, respectively (Table 1). All of the PVY isolates detected in the asymptomatic composite samples were $P V Y^{\mathrm{O}}$.

In the symptomatic samples collected in 2002, PVS and PVY were the only viruses detected as single infections, in 4 and $11 \%$ of the samples, respectively, and they also were the most common mixed infection.
Other combinations also were identified at lower frequencies (Table 2). In the symptomatic samples collected in 2003, PVS, PVY, and PLRV were detected as single infections, with PVY representing the majority $(32 \%)$ of single infections. A variety of combinations of mixed infections also were observed (Table 2).

At the time of sampling, the potato cultivar name was recorded (when known) and, in 2003, the number of samples of each cultivar testing positive for any of the six different viruses was compiled (Table 3). High proportions of the symptomatic samples of the breeding lines tested positive for PVS, PVX, and PVY, as did four of the most widely grown potato cultivars in the United States, Russet Burbank, Russet Norkotah, Shepody, and Snowden. These three viruses also were observed in the composite, asymptomatic samples of Russet Norkotah and Shepody (Table 3).

PVY isolate characterization. Of the PVY isolates detected, $98 \%$ were similar to the ordinary strain, $\mathrm{PVY}^{\mathrm{O}}$. In infected tobacco plants, they induced a typical mild mosaic without any observable veinal necrosis. These isolates did not react with
MAb 1F5, and no further characterization was attempted. Of the 394 PVY isolates, 8 induced veinal necrosis in tobacco or reacted with MAb 1F5 (Table 4) and were the subject of additional work. Two type strains (PV-575 and PV-576) and four isolates from the western United States (AL1, AL2, RR1, and FL40D) were used as reference isolates. Isolate $\mathrm{PB} 252$ reacted with MAb 1F5 and induced veinal necrosis in tobacco, but did not cause tuber necrosis. However, PB252 and most other necrosis-inducing isolates in this study were not typical $\mathrm{PVY} \mathrm{N}^{\mathrm{N}}$ strains in that they also were detected by the PVY ${ }^{\mathrm{O}}$ MAb 2 (Table 4). This suggests that these isolates were either mixed infections of $\mathrm{PVY}^{\mathrm{O}}$ and $\mathrm{PVY}^{\mathrm{N}}$ antigenic strains, or their capsid proteins had an unusual combination of antigenic sites.

Isolates PB312 and PB313 caused tuber necrosis in greenhouse-grown Yukon Gold (Table 5; Fig. 1), induced veinal necrosis in tobacco, and reacted with MAb 1F5. Therefore, these two isolates can be classified as PVY ${ }^{\text {NTN }}$ isolates. In subsequent studies, field-grown Yukon Gold infected with PB312 also yielded tubers with tuber

Table 3. Frequency of Potato virus A (PVA), Potato virus $M$ (PVM), Potato virus $S$ (PVS), Potato virus $X$ (PVX), Potato virus $Y$ (PVY), and Potato leafroll virus (PLRV) in potato cultivars sampled in 2003

\begin{tabular}{|c|c|c|c|c|c|c|c|c|c|c|c|c|}
\hline \multirow[b]{2}{*}{ Potato cultivars $^{\mathrm{c}}$} & \multicolumn{6}{|c|}{ Symptomatic samples ${ }^{a}$} & \multicolumn{6}{|c|}{ Asymptomatic samples ${ }^{\text {b }}$} \\
\hline & PVA & PVM & PVS & PVX & PVY & PLRV & PVA & PVM & PVS & PVX & PVY & PLRV \\
\hline Breeding lines & $0 / 83$ & $0 / 83$ & $28 / 83$ & $3 / 83$ & $68 / 83$ & $0 / 83$ & $0 / 6$ & $0 / 6$ & $3 / 6$ & $0 / 6$ & $1 / 6$ & $0 / 6$ \\
\hline Unknown & $0 / 62$ & $0 / 62$ & $34 / 62$ & $3 / 62$ & $8 / 62$ & $1 / 62$ & $0 / 37$ & $0 / 37$ & $18 / 37$ & $2 / 37$ & $1 / 37$ & $0 / 37$ \\
\hline Shepody & $1 / 35$ & $0 / 35$ & $18 / 35$ & $7 / 35$ & $34 / 35$ & $0 / 35$ & $0 / 7$ & $0 / 7$ & $5 / 7$ & $3 / 7$ & $3 / 7$ & $0 / 7$ \\
\hline Russet Burbank & $0 / 19$ & $0 / 19$ & $17 / 19$ & $6 / 19$ & $18 / 19$ & $0 / 19$ & $0 / 3$ & $0 / 3$ & $3 / 3$ & $0 / 3$ & $0 / 3$ & $0 / 3$ \\
\hline Monona & $0 / 14$ & $0 / 14$ & $4 / 14$ & $2 / 14$ & $4 / 14$ & $0 / 14$ & $0 / 0$ & $0 / 0$ & $0 / 0$ & $0 / 0$ & $0 / 0$ & $0 / 0$ \\
\hline Pike & $0 / 14$ & $0 / 14$ & $4 / 14$ & $0 / 14$ & $10 / 14$ & $0 / 14$ & $0 / 0$ & $0 / 0$ & $0 / 0$ & $0 / 0$ & $0 / 0$ & $0 / 0$ \\
\hline Snowden & $0 / 14$ & $0 / 14$ & $8 / 14$ & $2 / 14$ & $8 / 14$ & $0 / 14$ & $0 / 1$ & $0 / 1$ & $0 / 1$ & $0 / 1$ & $0 / 1$ & $0 / 1$ \\
\hline Russet Norkotah & $0 / 9$ & $0 / 9$ & $9 / 9$ & $4 / 9$ & 9/9 & $0 / 9$ & $0 / 7$ & $0 / 7$ & $6 / 7$ & $1 / 7$ & $2 / 7$ & $0 / 7$ \\
\hline Reba & $0 / 8$ & $0 / 8$ & $1 / 8$ & $0 / 8$ & $0 / 8$ & $0 / 8$ & $0 / 1$ & $0 / 1$ & $0 / 1$ & $0 / 1$ & $0 / 1$ & $0 / 1$ \\
\hline Atlantic & $0 / 6$ & $0 / 6$ & $3 / 6$ & $0 / 6$ & $5 / 6$ & $0 / 6$ & $0 / 1$ & $0 / 1$ & $1 / 1$ & $0 / 1$ & $1 / 1$ & $0 / 1$ \\
\hline Bake King & $0 / 6$ & $0 / 6$ & $4 / 6$ & $0 / 6$ & $6 / 6$ & $0 / 6$ & $0 / 0$ & $0 / 0$ & $0 / 0$ & $0 / 0$ & $0 / 0$ & $0 / 0$ \\
\hline Goldrush & $0 / 6$ & $0 / 6$ & $4 / 6$ & $0 / 6$ & $5 / 6$ & $0 / 6$ & $0 / 2$ & $0 / 2$ & $2 / 2$ & $0 / 2$ & $0 / 2$ & $0 / 2$ \\
\hline Andover & $0 / 5$ & $0 / 5$ & $0 / 5$ & $0 / 5$ & $3 / 5$ & $0 / 5$ & $0 / 0$ & $0 / 0$ & $0 / 0$ & $0 / 0$ & $0 / 0$ & $0 / 0$ \\
\hline Superior & $0 / 5$ & $0 / 5$ & $4 / 5$ & $0 / 5$ & $5 / 5$ & $0 / 5$ & $0 / 1$ & $0 / 1$ & $1 / 1$ & $0 / 1$ & $0 / 1$ & $0 / 1$ \\
\hline Green Mountain & $0 / 4$ & $0 / 4$ & $3 / 4$ & $0 / 4$ & $4 / 4$ & $0 / 4$ & $0 / 2$ & $0 / 2$ & $2 / 2$ & $0 / 2$ & $1 / 2$ & $0 / 2$ \\
\hline Ontario & $0 / 4$ & $0 / 4$ & $2 / 4$ & $0 / 4$ & $2 / 4$ & $0 / 4$ & $0 / 1$ & $0 / 1$ & $1 / 1$ & $0 / 1$ & $0 / 1$ & $0 / 1$ \\
\hline La Chipper & $0 / 3$ & $0 / 3$ & $0 / 3$ & $0 / 3$ & $3 / 3$ & $0 / 3$ & $0 / 1$ & $0 / 1$ & $0 / 1$ & $0 / 1$ & $0 / 1$ & $0 / 1$ \\
\hline Chieftain & $0 / 2$ & $0 / 2$ & $2 / 2$ & $0 / 2$ & $0 / 2$ & $0 / 2$ & $0 / 0$ & $0 / 0$ & $0 / 0$ & $0 / 0$ & $0 / 0$ & $0 / 0$ \\
\hline Krantz & $0 / 2$ & $0 / 2$ & $1 / 2$ & $0 / 2$ & $1 / 2$ & $1 / 2$ & $0 / 1$ & $0 / 1$ & $1 / 1$ & $0 / 1$ & $0 / 1$ & $0 / 1$ \\
\hline Norland & $0 / 2$ & $0 / 2$ & $0 / 2$ & $0 / 2$ & $2 / 2$ & $0 / 2$ & $0 / 0$ & $0 / 0$ & $0 / 0$ & $0 / 0$ & $0 / 0$ & $0 / 0$ \\
\hline Purple Viking & $0 / 2$ & $0 / 2$ & $2 / 2$ & $0 / 2$ & $2 / 2$ & $0 / 2$ & $0 / 0$ & $0 / 0$ & $0 / 0$ & $0 / 0$ & $0 / 0$ & $0 / 0$ \\
\hline Ranger Russet & $0 / 2$ & $0 / 2$ & $2 / 2$ & $0 / 2$ & $2 / 2$ & $0 / 2$ & $0 / 0$ & $0 / 0$ & $0 / 0$ & $0 / 0$ & $0 / 0$ & $0 / 0$ \\
\hline Caribe & $0 / 1$ & $0 / 1$ & $0 / 1$ & $0 / 1$ & $1 / 1$ & $0 / 1$ & $0 / 0$ & $0 / 0$ & $0 / 0$ & $0 / 0$ & $0 / 0$ & $0 / 0$ \\
\hline Eva & $0 / 1$ & $0 / 1$ & $1 / 1$ & $0 / 1$ & $0 / 1$ & $0 / 1$ & $0 / 0$ & $0 / 0$ & $0 / 0$ & $0 / 0$ & $0 / 0$ & $0 / 0$ \\
\hline Gold Dust & $0 / 1$ & $0 / 1$ & $0 / 1$ & $0 / 1$ & $1 / 1$ & $0 / 1$ & $0 / 0$ & $0 / 0$ & $0 / 0$ & $0 / 0$ & $0 / 0$ & $0 / 0$ \\
\hline Norland "Dark Red" & $0 / 1$ & $0 / 1$ & $1 / 1$ & $0 / 1$ & $0 / 1$ & $0 / 1$ & $0 / 0$ & $0 / 0$ & $0 / 0$ & $0 / 0$ & $0 / 0$ & $0 / 0$ \\
\hline Norland "Red" & $0 / 1$ & $0 / 1$ & $1 / 1$ & $0 / 1$ & $1 / 1$ & $0 / 1$ & $0 / 0$ & $0 / 0$ & $0 / 0$ & $0 / 0$ & $0 / 0$ & $0 / 0$ \\
\hline Norwis & $0 / 1$ & $0 / 1$ & $1 / 1$ & $0 / 1$ & $1 / 1$ & $0 / 1$ & $0 / 0$ & $0 / 0$ & $0 / 0$ & $0 / 0$ & $0 / 0$ & $0 / 0$ \\
\hline Yukon Gold & $0 / 1$ & $0 / 1$ & $1 / 1$ & $0 / 1$ & $0 / 1$ & $0 / 1$ & $0 / 0$ & $0 / 0$ & $0 / 0$ & $0 / 0$ & $0 / 0$ & $0 / 0$ \\
\hline Dakota Pearl & $0 / 0$ & $0 / 0$ & $0 / 0$ & $0 / 0$ & $0 / 0$ & $0 / 0$ & $0 / 1$ & $0 / 1$ & $1 / 1$ & $0 / 1$ & $0 / 1$ & $0 / 1$ \\
\hline Frito-Lay Variety 1867 & $0 / 0$ & $0 / 0$ & $0 / 0$ & $0 / 0$ & $0 / 0$ & $0 / 0$ & $0 / 1$ & $0 / 1$ & $1 / 1$ & $0 / 1$ & $0 / 1$ & $0 / 1$ \\
\hline Keuka Gold & $0 / 0$ & $0 / 0$ & $0 / 0$ & $0 / 0$ & $0 / 0$ & $0 / 0$ & $0 / 1$ & $0 / 1$ & $1 / 1$ & $0 / 1$ & $0 / 1$ & $0 / 1$ \\
\hline Penta & $0 / 0$ & $0 / 0$ & $0 / 0$ & $0 / 0$ & $0 / 0$ & $0 / 0$ & $0 / 1$ & $0 / 1$ & $1 / 1$ & $1 / 1$ & $0 / 1$ & $0 / 1$ \\
\hline Sante & $0 / 0$ & $0 / 0$ & $0 / 0$ & $0 / 0$ & $0 / 0$ & $0 / 0$ & $0 / 1$ & $0 / 1$ & $1 / 1$ & $0 / 1$ & $0 / 1$ & $0 / 1$ \\
\hline
\end{tabular}

${ }^{a}$ Virus symptoms included necrotic lesions, leaf mosaic, leaf mottling, rugosity, stunting, and discoloration.

${ }^{\mathrm{b}}$ Composite samples consisted of leaves from 10 asymptomatic plants, tested as one sample.

${ }^{\mathrm{c}}$ Potato cultivars are named cultivars; breeding lines are numbered clones under evaluation. Data from breeding lines and unknown cultivars are respectively grouped for this table. Shaded data signify at least one positive sample infected with a virus. Cultivars not testing positive for any of the six viruses were All Blue, Banana, Mainestay, Marcy, and Salem. Data are expressed as the number of positive samples/number of samples tested. 
necrosis, confirming the greenhouse assay (data not shown). PB313 differed from PB312 in that it reacted with MAb 2, whereas PB312 did not (Table 4). The reference isolate FL40D induced tuber necrosis symptoms in Yukon Gold that differed from those caused by the other tuber necrosis-inducing isolates. The necrosis often was more advanced in the stem end of a symptomatic tuber infected with FL40D (Fig. 1A). The tuber necrosis symptoms caused by the reference isolate RR1 and survey isolates PB312 and PB313 were the more typical raised necrotic rings, usually around tuber eyes; the severity of these symptoms increased after storage at $4^{\circ} \mathrm{C}$ (Fig. 1B). Overall, FL40D induced a higher proportion of symptomatic tubers from infected plants and decreased the number of tubers produced per infected plant more than RR1, PB312, and PB313 (data not shown).

Two isolates, PB22 and PB209, were serologically related to $\mathrm{PVY}^{\mathrm{O}}$ and did not react with MAb 1F5; however, they did induce veinal necrosis in tobacco similar to $\mathrm{PVY}^{\mathrm{N}}$. They did not induce tuber necrosis in Yukon Gold under the conditions described (Table 5). Based on these results, PB22 and PB209 resemble isolates referred to as PVY-Wilga (6) or PVY ${ }^{\mathrm{N}: \mathrm{O}}$ isolates (30) (Table 4).
PB315, PB343, and PB419 did not induce veinal necrosis in tobacco, although they were detected by MAb 1F5 and MAb 2 (Table 4). We have designated isolates that react with both 1F5 and MAb 2 but do not induce veinal necrosis in tobacco as $\mathrm{O}_{5}$, consistent with the system of Ellis et al. (12). PB419 and PB343 did not cause tuber necrosis symptoms in Yukon Gold and, surprisingly, PB315 did not systemically infect Yukon Gold plants. Mechanical inoculation of other potato cultivars with PB315 consistently resulted in systemic infections (Table 6). In one of the tuber necrosis tests, PB343 infection yielded tubers showing symptoms resembling

Table 4. Bioassay and monoclonal antibody (MAb) recognition of Potato virus $Y$ (PVY) reference isolates and isolates from the northeastern United States

\begin{tabular}{|c|c|c|c|c|c|}
\hline PVY isolate $^{a}$ & Veinal necrosis in tobacco & MAb 1F5 reactivity ${ }^{b}$ & MAb 2 reactivity ${ }^{c}$ & Tuber necrosis in Yukon Gold ${ }^{d}$ & Strain designation ${ }^{\mathrm{e}}$ \\
\hline PV-Oz & No & - & + & No & $\mathrm{PVYO}^{\mathrm{O}}$ \\
\hline PV-575 & No & - & + & No & $\mathrm{PVY}^{\mathrm{O}}$ \\
\hline PV-576 & No & - & + & No & PVYC \\
\hline AL1 & Yes & - & + & $\mathrm{No}^{\mathrm{f}}$ & $\mathrm{PVY}^{\mathrm{N}: \mathrm{O}}$ \\
\hline AL2 & Yes & - & + & No & PVY ${ }^{\mathrm{N}: \mathrm{O}}$ \\
\hline RR1 & Yes & + & - & Yes & PVY ${ }^{\mathrm{NTN}}$ \\
\hline FL40D & Yes & + & - & Yes & PVYNTN \\
\hline PB22 & Yes & - & + & No & $P V Y^{\mathrm{N}: \mathrm{O}}$ \\
\hline PB209 & Yes & - & + & No & $\mathrm{PVY}^{\mathrm{N}: \mathrm{O}}$ \\
\hline PB252 & Yes & + & + & No & $\mathrm{PVY}^{\mathrm{N}}$ \\
\hline PB312 & Yes & + & - & Yes & PVYNTN \\
\hline PB313 & Yes & + & + & Yes & PVYNTN \\
\hline PB315 & No & + & + & N.I. & $\mathrm{O}_{5}$ \\
\hline PB343 & No & + & + & No & $\mathrm{O}_{5}$ \\
\hline PB419 & No & + & + & No & $\mathrm{O}_{5}$ \\
\hline
\end{tabular}

${ }^{\text {a }} \mathrm{PVY}-\mathrm{Oz}$ is an ordinary strain $\left(\mathrm{PVY}^{\mathrm{O}}\right)$ isolate obtained from New York State-grown potato. PV-575 and PV-576 are the American Type Culture Collection reference isolates for $\mathrm{PVY} \mathrm{Y}^{\mathrm{O}}$ and the stipple-streak strain $\left(\mathrm{PVY}^{\mathrm{C}}\right)$, respectively (45). AL1, AL2, RR1, and FL40D are reference isolates obtained in surveys conducted in the northwestern United States (8).

${ }^{\mathrm{b}}$ MAb 1F5 is used in triple-antibody sandwich enzyme-linked immunosorbent assay (TAS-ELISA) (11) to detect the necrotic strain (PVYN $)$-associated antigen.

${ }^{\mathrm{c}} \mathrm{MAb} 2$ is used in TAS-ELISA to detect an antigen common to most PVYO and PVYC isolates (11).

${ }^{\mathrm{d}}$ PVY isolates were inoculated mechanically onto tuber necrosis-susceptible greenhouse-grown Solanum tuberosum cv. Yukon Gold plants. N.I.= Yukon Gold was not infected by PB315.

${ }^{\mathrm{e}}$ Strain designations are based on MAb 1F5 and MAb 2 recognition and tobacco and potato cv. Yukon Gold bioassays. See text for $\mathrm{O}_{5}$ strain characterization.

${ }^{\mathrm{f}}$ AL1 was reported to cause tuber necrosis in the potato cv. Alturas (8).

Table 5. Tuber necrosis in greenhouse-grown, Potato virus $Y$ (PVY)-inoculated Yukon Gold potato plants

\begin{tabular}{|c|c|c|c|c|c|c|}
\hline \multirow[b]{2}{*}{ Planting date ${ }^{b}$} & \multicolumn{6}{|c|}{ PVY isolate ${ }^{a}$} \\
\hline & AL1 & RR1 & FL40D & PB312 & PB313 & PB343 \\
\hline 29 October 2003 & $\ldots$ & & & $12 / 15(35 / 45)$ & $\ldots$ & $\ldots$ \\
\hline 7 November 2003 & $\ldots$ & $0 / 4(0 / 0)$ & $1 / 4(1 / 1)$ & $\ldots$ & $\ldots$ & $\ldots$ \\
\hline 17 January 2004 & $\ldots$ & $4 / 4(11 / 14)$ & $4 / 4(8 / 11)$ & $3 / 4(6 / 16)$ & $3 / 4(6 / 16)$ & $0 / 4(0 / 12)^{\mathrm{c}}$ \\
\hline 17 January $2004^{d}$ & $\ldots$ & $2 / 3(3 / 15)$ & $2 / 3(2 / 11)$ & $0 / 3(0 / 19)$ & & $0 / 3(0 / 13)$ \\
\hline 2 April 2004 & $0 / 5(0 / 31)^{\mathrm{c}}$ & $1 / 3(1 / 10)$ & $3 / 5(6 / 12)$ & $4 / 5(8 / 21)$ & $4 / 5(9 / 25)$ & $\ldots$ \\
\hline 4 May 2004e & $0 / 4(0 / 20)$ & $3 / 4(3 / 21)$ & $0 / 4(0 / 8)$ & $2 / 4(2 / 15)$ & $0 / 4(0 / 9)$ & $0 / 2(0 / 8)$ \\
\hline 4 June 2004 & $0 / 4(0 / 23)$ & $1 / 1(1 / 3)$ & $4 / 4(19 / 19)$ & $4 / 4(7 / 14)$ & & $\ldots$ \\
\hline 23 July 2004 & $\ldots$ & $\ldots$ & $4 / 4(8 / 10)$ & $4 / 4(14 / 15)$ & $1 / 4(3 / 18)$ & $0 / 26(0 / 26)$ \\
\hline 2 September 2004 & $\ldots$ & $\ldots$ & $3 / 3(13 / 20)$ & $2 / 3(10 / 15)$ & $\ldots$ & $0 / 5(0 / 38)$ \\
\hline
\end{tabular}

${ }^{a}$ Data without parentheses are the number of plants with tuber necrosis symptoms/number of plants testing positive for PVY by double-antibody sandwich enzyme-linked immunosorbent assay. Data within parentheses are the number of tubers with tuber necrosis symptoms/number of total tubers. Isolates that never showed tuber necrosis were PVY-Oz (three planting dates, 24 plants infected, 89 tubers), AL2 (two planting dates, 8 plants infected, 23 tubers), PB22 (three planting dates, 10 plants infected, 56 tubers), PB209 (five planting dates, 38 plants infected, 147 tubers), PB252 (five planting dates, 18 plants infected, 100 tubers), and PB419 (four planting dates, 6 plants infected, 15 tubers). Twelve Yukon Gold plants were inoculated with PB315 in three different experiments; none became infected.

${ }^{b}$ Plants emerged 2 to 4 weeks after sprouted tubers were planted and were inoculated 2 to 4 weeks post emergence unless otherwise noted. All tubers from experiments were harvested between 50 and 65 days post inoculation unless otherwise noted.

${ }^{c}$ Symptoms observed on 6 of 31 tubers from three of five plants infected with AL1 and 3 of 12 tubers from three of four plants infected with PB343 were different from the typical tuber necrosis induced by other isolates. Tuber symptom severity did not increase after 2 months of storage, as was observed with tuber necrosis symptoms induced by other isolates. The induction of tuber necrosis by PB343 could not be confirmed in progeny derived from plants grown from tubers with atypical symptoms.

${ }^{\mathrm{d}}$ Plants in this experiment were inoculated 76 days post planting (62 days post emergence) and harvested 24 days post inoculation.

${ }^{\mathrm{e}}$ Experiment harvested 58 days after planting (at least 18 days shorter than all other experiments). 
tuber necrosis, as did the reference isolate AL1 (Table 5; Fig. 1C). However, these atypical tuber necrosis symptoms were not reproduced in four repeated experiments for PB343 and two repeated experiments for AL1, and may have been due to other factors, such as environmental (greenhouse) conditions. Furthermore, plants sprouted from these tubers with atypical symptoms did test positive for PVY and were grown to maturity, but no daughter tubers with necrotic symptoms were observed. PVY reference isolates RR1 and FL40D reproducibly yielded tubers expressing necrosis when inoculated onto Yukon Gold (Table 5; Fig. 1).

Differential inoculations and reactions to $\boldsymbol{R y}$ and $\mathrm{Ny}$ resistance genes. Previous work with $S$. brachycarpum as an indicator plant showed that $\mathrm{PVY}^{\mathrm{O}}$ and $\mathrm{PVY}^{\mathrm{C}}$ induced mosaic symptoms and that $\mathrm{PVY}^{\mathrm{N}}$ induced necrosis (37). This proved to be the case with all the tested isolates (8) and those from this study except for RR1, which induced a mild mosaic in S. brachycarpum (Table 6). We also expected $\mathrm{PVY}^{\mathrm{N}: \mathrm{O}}$ isolates (AL1, AL2, PB22, and PB209) infecting S. brachycarpum to induce mosaic symptoms, similar to other North American PVY N:O isolates (39); however, AL1, PB22, and PB209 induced veinal necrosis, similar to related European PVY-Wilga isolates (39; Table 6). $\mathrm{O}_{5}$ isolates (PB315, PB343, and PB419) induced mosaic symptoms in $S$. brachycarpum similar to the $\mathrm{PVY}^{\mathrm{O}}$ and $\mathrm{PVY}^{\mathrm{C}}$ isolates (Table 6), even though these isolates displayed the $\mathrm{PVY}^{\mathrm{N}}$-associated antigen recognized by MAb 1F5 (Table 4).

The potato cv. Allegheny is a local lesion host for PVY (49). All of the PVYO, $\mathrm{PVY}^{\mathrm{C}}$, and $\mathrm{O}_{5}$ isolates induced local lesions with or without a subsequent systemic infection. In contrast, $\mathrm{PVY} \mathrm{N}^{\mathrm{N}}$ isolates, including PVY ${ }^{\mathrm{NTN}}$ and PVY ${ }^{\mathrm{N}: \mathrm{O}}$, systemically infected Allegheny without local lesion induction, with one exception. The $\mathrm{PVY}^{\mathrm{NTN}}$ isolate PB312 induced both local lesions and a systemic mosaic in Allegany. Both the potato breeding line NY115 and cv. Atlantic were infected systemically by all isolates but did not always show symptoms. Inoculated plants of the PVYresistant potato cv. Eva did not express local or systemic symptoms and virus was not detected in the noninoculated leaves (Table 6).

\section{DISCUSSION}

Consistent with recent reports from potato-growing regions in the western and central parts of North America $(8,35)$, we have observed necrotic isolates and antigenic variants of PVY in the northeastern United States. Although the frequency at which these isolates were recovered was low $(2 \%)$, it is clear that necrotic PVY and other variants are widespread and becoming more prevalent. A part of the increase can be attributed to PVY asymptomatic
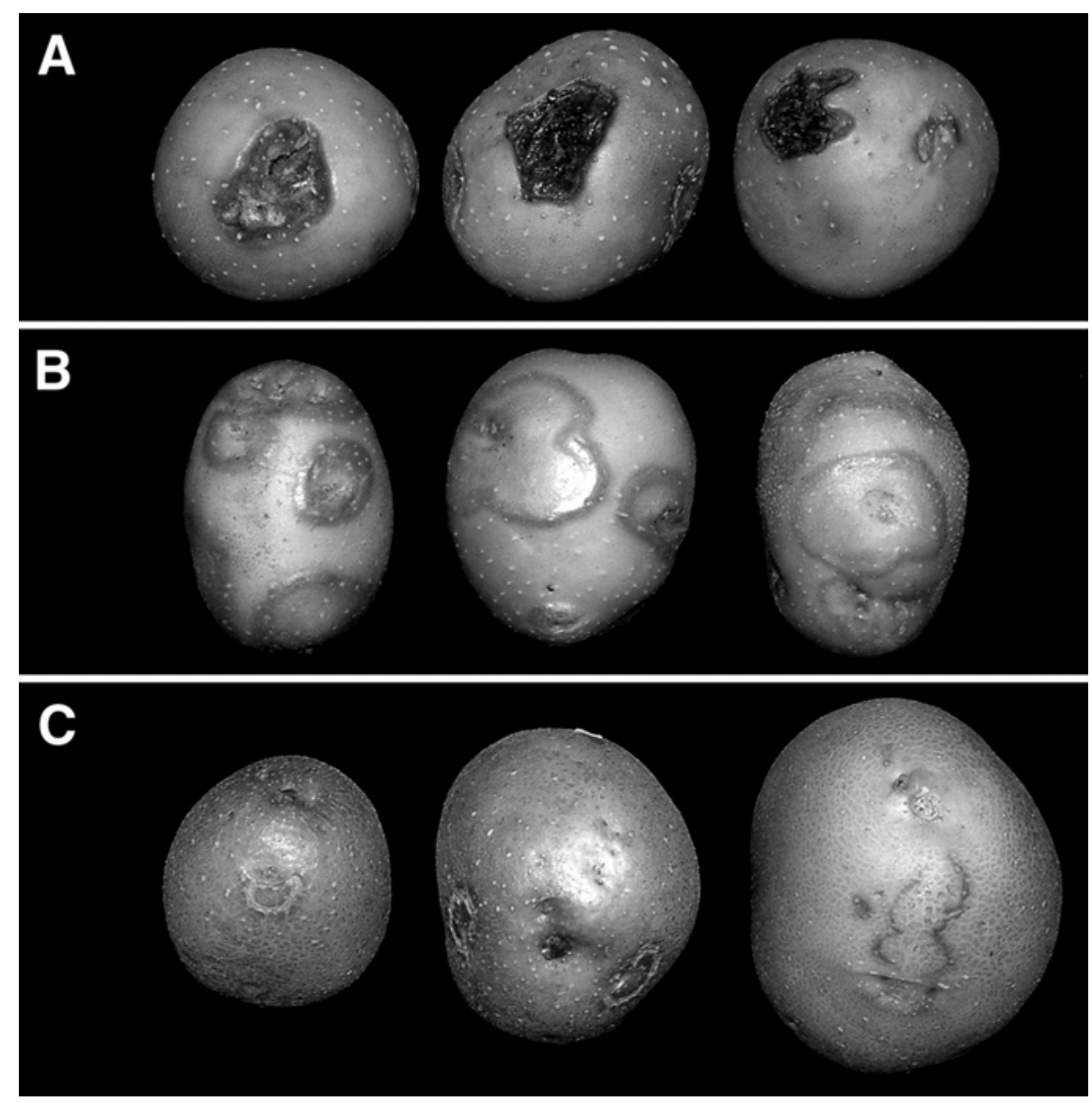

Fig. 1. Potato virus $Y$ (PVY) isolate symptoms in greenhouse-grown potato cv. Yukon Gold tubers harvested 52 to 65 days post inoculation. A, Tuber necrosis induced by the PVY strain able to induce necrosis in tobacco and in potato tubers $\left(\mathrm{PVY}^{\mathrm{NTN}}\right)$ reference isolate FL40D showing the advanced necrosis at the stem-end of the tubers after 11 weeks of storage at $4^{\circ} \mathrm{C} ; \mathbf{B}$, typical PVY ${ }^{\mathrm{NTN}}$ symptoms induced by the survey isolate PB312 with the raised necrotic rings around the tuber eyes after 5 weeks of storage at $4^{\circ} \mathrm{C}$; and $\mathrm{C}$, atypical tuber necrosis induced by PVY ${ }^{\mathrm{N}: \mathrm{O}}$ reference isolate AL1 which were not exacerbated after 21 weeks of storage at $4^{\circ} \mathrm{C}$.

Table 6. Infection and symptom induction in Solanum brachycarpum, S. tuberosum breeding line NY115, and S. tuberosum cvs. Atlantic, Eva, and Allegany after mechanical inoculation with Potato virus $Y(\mathrm{PVY})$ isolates

\begin{tabular}{llllll}
\hline & \multicolumn{5}{c}{ Potato genotype $^{\mathbf{a}}$} \\
\cline { 2 - 6 } PVY isolate $^{\mathbf{b}}$ & ${\text { S. } \text { brachycarpum }^{\mathbf{c}}}$ & Allegany & NY115 & Atlantic & Eva \\
\hline PVY-Oz & MM & LL, SM & SM & SM & None \\
PV-575 & MM & LL & MM & MM & None \\
PV-576 & MM & LL & SI & SI & None \\
AL1 & MM & SI & SI & SI & None \\
AL2 & LL, VN & SI & SI & SI & None \\
RR1 & MM & MM & SI & SI & None \\
FL40D & LL, VN, lethal & M & SI & MM & None \\
PB22 & LL, VN & SI & MM & SI & None \\
PB209 & LL, VN & MM & MM & MM & None \\
PB252 & LL, VN & SI & MM & MM & None \\
PB312 & LL, VN, lethal & LL, M & MM & MM & None \\
PB313 & LL, VN, lethal & MM & SI & MM & None \\
PB315 & M & LL, SI & MM & MM & None \\
PB343 & MM & LL & M & SM & None \\
PB419 & MM & LL & SM & SM & None \\
\hline
\end{tabular}

${ }^{a}$ Symptoms were noted 8 and 21 days post inoculation (dpi). MM = systemic mild mosaic, $L L=$ local lesions on inoculated leaf, SM = systemic severe mosaic, None $=$ no local or systemic symptoms and systemic leaves tested negative by enzyme-linked immunosorbent assay (ELISA), SI = symptomless infection based on ELISA data from systemic leaves, $\mathrm{VN}=$ systemic veinal necrosis, lethal = plant was dead at $21 \mathrm{dpi}$, and $\mathrm{M}=$ systemic mosaic.

${ }^{b}$ PVY-Oz is an ordinary strain $\left(\mathrm{PVY}^{\mathrm{O}}\right)$ isolate obtained from New York State-grown potato. PV-575 and PV-576 are the American Type Culture Collection reference isolates for PVYO and the stipplestreak strain $\left(\mathrm{PVY}^{\mathrm{C}}\right)$, respectively (45). AL1, AL2, RR1, and FL40D are reference isolates obtained in surveys conducted in the northwestern United States (8).

'Symptoms on S. brachycarpum induced by some isolates varied between experiments; the most severe symptoms are reported. 
cultivars such as Russet Norkotah and Shepody $(16,18,44)$. PVY infection of Russet Norkotah and Shepody results in decreased yield (33), but the greater impact on production is likely to be that these asymptomatic plants function as a virus reservoir, facilitating in-season spread by aphids not only to plants in the same field but also to other cultivars in neighboring fields. Several isolates of PVY were identified in symptomatic and asymptomatic Russet Norkotah and Shepody (Table 3), emphasizing that other factors in addition to host genotype are involved in symptom development (e.g., time of infection, virus strain, mixed infections, and environment). $\mathrm{PVY}^{\mathrm{N}}, \mathrm{PVY}^{\mathrm{NTN}}$, or PVY ${ }^{\mathrm{N}: \mathrm{O}}$ isolates were not observed in the asymptomatic composite samples, although this is not surprising given the relatively small sample size. Several of these isolates did establish asymptomatic infections in NY115, Atlantic, and Allegany in greenhouse tests (Table 6).

PVY susceptibility and symptom expression are taken into account in breeding new potato cultivars $(27,34,43)$, but yield and quality traits take precedence. Therefore, many breeding lines lack any effective PVY resistance, as evidenced by the high incidence of PVY associated with breeding lines sampled in this survey (Table 3). PVY will continue to hinder production until desirable cultivars possessing effective PVY resistance are released and accepted by the industry.

There are similarities between the PVY observed in this study and North American isolates previously reported. In 1989, a $\mathrm{PVY}^{\mathrm{N}}$ isolate was discovered in tobacco fields in Ontario, Canada. Subsequent surveys of potato grown in eastern Canadian provinces and table stock potato imported to Canada from California yielded closely related $\mathrm{PVY}^{\mathrm{N}}$ isolates (23), some of which later were shown to be PVY ${ }^{\text {NTN }}$ isolates (24). More than half of the PVY isolates identified in a survey conducted in Manitoba, Canada in 1998 through 2002 were shown to be $\mathrm{PVY}^{\mathrm{N}: \mathrm{O}}$. Further investigations in 2002 showed that $\mathrm{PVY}^{\mathrm{N}: \mathrm{O}}$ isolates were in potato seed lots originating from Minnesota, Montana, North Dakota, and Manitoba (39). In 2002, several PVY ${ }^{\mathrm{N}}$ and PVY ${ }^{\text {NTN }}$ isolates were reported in the western United States potato-growing regions. One of the tobacco veinal necrosis-inducing isolates (AL1) did not react with $\mathrm{PVY}^{\mathrm{N}} \mathrm{MAb}$, was shown to have a coat protein sequence similar to $\mathrm{PVY}^{\mathrm{O}}$, and caused tuber necrosis in the potato $\mathrm{cv}$. Alturas (8). The identification of $\mathrm{PVY}^{\mathrm{N}}$, $\mathrm{PVY}^{\mathrm{NTN}}$, and $\mathrm{PVY}^{\mathrm{N}: \mathrm{O}}$ isolates in North American potato-producing regions continues to be a priority, given the national and international trafficking of potato seed and the sensitivity of these viruses with regard to quarantine and trade issues.

PB252, PB312, and PB313 are the first $\mathrm{PVY}^{\mathrm{N}}$ or PVY ${ }^{\mathrm{NTN}}$ isolates to be described in potato grown in the northeastern United
States. However, PB252 and PB313 are atypical in that they also react with MAb 2 in addition to MAb 1F5 (Table 4). One explanation for this phenotype is that these isolates are mixed infections of two or more strains with different antigenicities. PB252 could be a mixed infection of $\mathrm{PVY}^{\mathrm{N}}$ and $\mathrm{PVY} \mathrm{Y}^{\mathrm{O}}$, whereas $\mathrm{PB} 313$ could be a mixture of $P V Y^{\mathrm{O}}$ and $P V Y^{\mathrm{NTN}}$. Alternatively, PB252 and PB313 may be $\mathrm{PVY}^{\mathrm{N}}$ or $\mathrm{PVY}^{\mathrm{NTN}}$ isolates, respectively, with coat proteins that are recognized by both $\mathrm{PVY}^{\mathrm{N}}$ and $\mathrm{PVY} \mathrm{Y}^{\mathrm{O}} \mathrm{MAbs}$. This could result from point mutations at one or more amino acid positions within an epitope or from a recombination event within the coat protein of PVY $(29,37)$ giving rise to isolates that possess both $\mathrm{PVY}^{\mathrm{N}}$ and $\mathrm{PVY}^{\mathrm{O}}$ antigens. It should be noted that not all isolates possessing the known coat protein recombinant junctions react with both MAb 1F5 and MAb 2 (35). PVYO isolates designated serotype $\mathrm{O}_{5}(12)$ react with both MAb 1F5 and MAb 2, but $\mathrm{PVY}^{\mathrm{N}}$ isolates reacting with both MAbs have not been reported.

Atypical tuber necrosis symptoms induced by $\mathrm{PVY}^{\mathrm{N}: \mathrm{O}}$ isolates have been reported (35). In our tests, AL2, PB22, and PB209 did not induce tuber necrosis in Yukon Gold whereas, in one trial, the reference isolate AL1 and isolate PB343 induced an atypical tuber necrosis (Table 5; Fig. 1C). These atypical tuber symptoms appear to be different from those recently reported for $\mathrm{PVY}^{\mathrm{N}: \mathrm{O}}$ isolates (35). AL1 also was reported to induce tuber necrosis in Alturas (8). It may be the case that Alturas is more susceptible to tuber necrosis than Yukon Gold, so that an isolate that causes limited atypical tuber necrosis in Yukon Gold would cause normal tuber necrosis in Alturas, but this has not been determined. Alternatively, unidentified environmental factors may have been conducive for the induction of tuber necrosis in the one particular trial. Research conducted in Europe has shown that several PVY isolates that cause veinal necrosis in tobacco also can induce potato tuber necrosis to varying degrees depending on environmental conditions (3); however, $\mathrm{PVY}^{\mathrm{N}: \mathrm{O}}$ isolates were not tested.

PB22 and PB209 appear to be similar to isolates referred to as PVY-Wilga (6) or $\mathrm{PVY}^{\mathrm{N}: \mathrm{O}}(30)$ that have arisen via a recombination event between $\mathrm{PVY}^{\mathrm{O}}$ and $\mathrm{PVY}^{\mathrm{N}}$ isolates $(2,15,32)$. These two isolates reacted with MAb 2, as do most $\mathrm{PVY}^{\mathrm{O}}$ and $\mathrm{PVY}^{\mathrm{C}}$ isolates (11), consistent with sequence data showing that $\mathrm{PVY}^{\mathrm{N}: \mathrm{O}}$ isolates resulted from $\mathrm{PVY}^{\mathrm{N}}$ and $\mathrm{PVY} \mathrm{Y}^{\mathrm{O}}$ recombination events $(15,25,32)$. Similar to many PVY isolates from this survey and reference isolates tested, both PB22 and PB209 induced necrosis in $S$. brachycarpum but not in Allegany (Table 6). Recently described North American PVY ${ }^{\mathrm{N}: \mathrm{O}}$ isolates did not induce necrosis in S. brachycarpum, whereas the recombinant PVY-Wilga isolates did (39). In this sense, the PVY ${ }^{\mathrm{N}: \mathrm{O}}$ isolates collected in this survey are more like the European PVY-Wilga isolates than other North American PVY $\mathrm{N}^{\mathrm{O} O}$ isolates. $\mathrm{PB} 22$, PB209, and other PVY ${ }^{\mathrm{N}: \mathrm{O}}$ isolates are a potential threat to the potato industry because they will not be identified as tobacco necrotic isolates by MAb-based screening methods. It is noteworthy that $\mathrm{PB} 22$ and PB209 were the only $2 \mathrm{PVY}^{\mathrm{N}: \mathrm{O}}$ isolates out of $394 \mathrm{PVY}$ isolates from this survey (Table 1). In 2004, PVY surveys were conducted in Maine, Oregon, and Washington potato seed-import plots (i.e., plots where samples from all imported seed lots are grown and observed for disease) where 14 of the 414 PVY samples reacted similarly to $\mathrm{PVY}^{\mathrm{N}: \mathrm{O}}$ isolates, in that they caused veinal necrosis in tobacco but did not react with MAb 1F5 in ELISA tests (S. Gray, unpublished data). These results contrast with the $63.5 \%$ of 361 total PVY isolates that were determined to be $\mathrm{PVY}^{\mathrm{N}: \mathrm{O}}$ in a recent survey conducted in the midwestern United States and central Canadian provinces (39). The apparent difference in the proportion of $\mathrm{PVY}^{\mathrm{N}: \mathrm{O}}$ isolates to other PVY isolates in the two regions is difficult to explain, although neither of these studies were random surveys. Given the rising prevalence of $\mathrm{PVY}^{\mathrm{N}: \mathrm{O}}$ isolates, as seen in the midwestern United States and central Canada $(25,39)$, these strains may be transmitted more efficiently by aphid vectors or in seed potato from infected plants into progeny tubers.

Isolates PB315, PB343, and PB419 compose an additional class of PVY isolates similar to $\mathrm{O}_{5}$ isolates previously reported (12). These isolates are PVY ${ }^{\mathrm{O}}$ based on their phenotype on tobacco (Table 4) and potato genotypes (Table 6); however, they react with MAb 1F5 and MAb 2 (Table 4). Additionally, these isolates induced local lesions on Allegany possessing hypersensitive resistance, as did the $\mathrm{PVY}^{\mathrm{O}}$ and $\mathrm{PVY}^{\mathrm{C}}$ reference isolates (Table 6). That PB315, PB343, and PB419 reacted with both MAb 1F5 and MAb 2 is most likely not a result of a mixed-strain infection because, in our observations of $\mathrm{PVY}^{\mathrm{N}}$ and $\mathrm{PVY}^{\mathrm{O}}$ mixed-strain infections (data not shown) and those of others (50), veinal necrosis is dominant and $\mathrm{PVY}^{\mathrm{O}}$ symptoms are masked. Additional testing is needed to determine the relationship of PB315, PB343, and PB419 to the $\mathrm{O}_{5}$ isolates reported in Idaho and several Canadian provinces (12). The $\mathrm{O}_{5}$ isolates are of significance to the potato industry, because they will give rise to false positives in surveys for $\mathrm{PVY}^{\mathrm{N}}$.

There are multiple sources and types of resistance to PVY in Solanum spp. (13). The $R y_{\text {and }}$ extreme resistance gene, as found in Eva, confers the most durable form of resistance. There are no examples in this study (Table 6) or in published reports where PVY isolates were able to overcome this extreme resistance. A less useful form of resistance is the hypersensi- 
tive resistance in Allegany. This was reported to be specific to $\mathrm{PVY} \mathrm{Y}^{\mathrm{O}}$ and to limit the spread of the virus (49). Several of the isolates reported in this study were able to induce local lesion formation and to spread systemically (Table 6).

One of the greatest challenges in characterizing PVY isolates is the possibility of mixed infections of multiple strains or viruses. A striking example is the synergism between PVX and PVY that can result in necrosis (9) and confound an assessment of the veinal necrosis phenotype. Although this was not observed in the present study, mixed infections were common and a majority of the infections analyzed in 2002 were mixed (Table 2). The most common mixed infection was that of PVY and PVS; these viruses were found alone or together in a majority of the samples in both years (Tables 1 and 2). PVS often is asymptomatic in the aboveground portions of the plant and is not known to induce tuber symptoms (14). Virus control measures in early-generation seed potato plants rely heavily on visual inspection and roguing of symptomatic plants; therefore, it was not surprising that PVS was common in the asymptomatic samples. PVS does have an economic impact, because single infections account for yield reductions of 10 to $20 \%$, and mixed infections with PVX or PVM reduce yield as much as $40 \%$ (14). PVM and PVA were common in 2002 (Table 2), probably due to the abundance of aphid vectors the previous season. These two viruses were barely detected in 2003, suggesting either that they were not transmitted efficiently from plants infected in 2002 to progeny tubers that were used as seed in 2003 or that they had been "flushed" out of the seed system (i.e., that certified seed with relatively little virus was planted as an alternative to replanting PVM- and PVAinfected seed).

The main purpose of this potato virus survey was to evaluate the diversity of PVY isolates in the northeastern United States potato-growing region. We employed a biased sampling method that provides information on the prevalence of PVY strain types. A number of the strains have not been reported previously in potato plants growing in the northeastern United States, and some presumptive recombinants are described. It will be of interest to gain a greater understanding of the genomic diversity among the $\mathrm{PVY}^{\mathrm{N}}, \mathrm{PVY}^{\mathrm{NTN}}$ and $\mathrm{PVY}^{\mathrm{N}: \mathrm{O}}$ isolates. $\mathrm{PVY}^{\mathrm{NTN}}$ strains pose the greatest threat to the potato industry, because they affect not only yield but also tuber quality. It remains to be determined what epidemiological factors and management practices have favored the increase in variant PVY.

\section{ACKNOWLEDGMENTS}

This work was supported, in part, by a USDA National Needs Fellowship, the New York State
Integrated Pest Management Program, the Maine Potato Board, and USDA-NRI program grant \#2003-05194 to K. L. Perry. We thank J. Crosslin and P. Shiel for providing PV-575, AL1, AL2, RR1, and FL40D PVY isolates; L. Miller, D. Smith, Q. Schneller, A. Raga, and the Cornell potato-breeding program for technical assistance with field collections and laboratory assays; K. Loeffler of Cornell University for the digital photography; Cornell Cooperative Extension agents J. Sieczka, D. Moyer, C. MacNeil, A. Seaman, C. Hoepting, S. Childs, R. Gast, and C. Albers for arranging field visits in New York; A. Todd of the Maine Seed Potato Board and the State of Maine potato seed inspectors for arranging field visits in Maine; and E. Fitzpatric, associated with the University of Maine, and R. Groves for assisting in Maine sampling in 2002.

\section{LITERATURE CITED}

1. Anonymous. 2004. 2003-2004 Potato Statistical Yearbook: National Potato Council, Washington, DC.

2. Boonham, N., Walsh, K., Preston, S., North, J., Smith, P., and Barker, I. 2002. The detection of tuber necrotic isolates of Potato virus $Y$, and the accurate discrimination of $\mathrm{PVY}^{\mathrm{O}}, \mathrm{PVY}^{\mathrm{N}}$ and $\mathrm{PVY}^{\mathrm{C}}$ strains using RT-PCR. J. Virol. Methods 102:103-112.

3. Browning, I., Charlet, K., Chrzanowska, M., Dedic, P., Kerlan, C., Kryszczuk, A., Schubert, J., Varveri, C., Werkman, A., and Wolf, I. 2004. What is PVYNTN? The Reaction of Potato Cultivars to Inoculation with a Range of PVY Isolates. 12th Eur. Assoc. Potato Res. Virol. Sect. Meeting, Rennes, France.

4. Celebi-Toprak, F., Slack, S. A., and Jahn, M. M. 2002. A new gene, $N y_{\text {tbr }}$, for hypersensitivity to Potato virus $Y$ from Solanum tuberosum maps to chromosome IV. Theor. Appl. Genet. 104:669-674.

5. Chachulska, A. M., Chrzanowska, M., Robaglia, C., and Zagorski, W. 1997. Tobacco veinal necrosis determinants are unlikely to be located within the $5^{\prime}$ and $3^{\prime}$ terminal sequences of the potato virus $\mathrm{Y}$ genome. Arch. Virol. 142:765-779.

6. Chrzanowska, M. 1994. Differentiation of potato virus Y (PVY) isolates. Phytopathol. Pol. 8:15-20.

7. Clark, M. F., and Adams, A. N. 1977. Characteristics of microplate method of enzymelinked immunosorbent assay for detection of plant viruses. J. Gen. Virol. 34:475-483.

8. Crosslin, J. M., Hamm, P. B., Eastwell, K. C., Thornton, R. E., Brown, C. R., Corsini, D., Shiel, P. J., and Berger, P. H. 2002. First report of the necrotic strain of Potato virus $Y\left(\mathrm{PVY}^{\mathrm{N}}\right)$ on potatoes in the northwestern United States. Plant Dis. 86:1177.

9. Damirdag, I. S., and Ross, A. F. 1967. A marked synergistic interaction of potato viruses $\mathrm{X}$ and $\mathrm{Y}$ in inoculated leaves of tobacco. Virology 31:296-307.

10. Dehaan, T. L. 1994. Seed potato certification and diagnostic testing. Can. J. Plant Pathol. 16:156-157.

11. Ellis, P., StaceSmith, R., Bowler, G., and Mackenzie, D. J. 1996. Production of monoclonal antibodies for detection and identification of strains of potato virus Y. Can. J. Plant Pathol. 18:64-70.

12. Ellis, P., StaceSmith, R., and deVilliers, G. 1997. Identification and geographic distribution of serotypes of potato virus Y. Plant Dis. 81:481-484.

13. Garcia-Arenal, F., and McDonald, B. A. 2003. An analysis of the durability of resistance to plant viruses. Phytopathology 93:941-952.

14. German, T. L. 2001. Potato Virus S. Pages 6768 in: Compendium of Potato Diseases, 2nd ed. W. R. Stevenson, R. Loria, G. D. Franc, and D. P. Weingartner, eds. American Phytopathology Society, St. Paul, MN

15. Glais, L., Tribodet, M., and Kerlan, C. 2002.
Genomic variability in Potato potyvirus $Y$ (PVY): evidence that $\mathrm{PVY}^{\mathrm{N}} \mathrm{W}$ and $\mathrm{PVY}^{\mathrm{NTN}}$ variants are single to multiple recombinants between $\mathrm{PVY}^{\mathrm{O}}$ and $\mathrm{PVY}^{\mathrm{N}}$ isolates. Arch. Virol. 147:363-378.

16. Hane, D. C., and Hamm, P. B. 1999. Effects of seedborne potato virus $\mathrm{Y}$ infection in two potato cultivars expressing mild disease symptoms. Plant Dis. 83:43-45.

17. Hutton, E. M., and Peak, J. W. 1952. Definition of potato virus Y strains by some Solanaceous species. Aust. J. Agric. Res. 3:1-7.

18. Johansen, R. H., Farnsworth, B., Gudmestad, N., Secor, G. A., Nelson, D. C., Thompson, A., Boe, A. A., and Orr, P. H. 1988. Russet Norkotah - a New Russet Potato Variety. N. D. Farm Res. 46:11-16.

19. Jones, R. A. C. 1990. Strain group-specific and virus-specific hypersensitive reactions to infection with potyviruses in potato cultivars. Ann. Appl. Biol. 117:93-105.

20. Kerlan, C., Tribodet, M., Glais, L., and Guillet, M. 1999. Variability of potato virus Y in potato crops in France. J. Phytopathol. 147:643-651.

21. Leromancer, M., and Kerlan, C. 1991. Superficial ringspot necrosis of potato-tubers - a recent disease caused by potato virus Y. Agronomie 11:889-900.

22. Makkouk, K. M., and Gumpf, D. J. 1974 Isolation and properties of potato virus Y ribonucleic acid. Phytopathology 64:1115-1118.

23. McDonald, J. G., and Kristjansson, G. T. 1993. Properties of strains of potato virus $\mathrm{Y}^{\mathrm{N}}$ in North America. Plant Dis. 77:87-89.

24. McDonald, J. G., and Singh, R. P. 1993. Assessment of North American isolates of PVYN for strains that induce tuber necrotic ring necrosis disease. Am. Potato J. 70:827.

25. McDonald, J. G., and Singh, R. P. 1996. Host range, symptomology, and serology of isolates of potato virus $\mathrm{Y}$ (PVY) that share properties with both the PVY ${ }^{\mathrm{N}}$ and $\mathrm{PVY} \mathrm{O}^{\mathrm{O}}$ strain groups. Am. Potato J. 73:309-315.

26. Mollov, D. S., and Thill, C. A. 2004. Heritability of asymptomatic expression to potato virus Y. Am. J. Potato Res. 81:75.

27. Mollov, D. S., and Thill, C. A. 2004. Evidence of Potato virus $Y$ asymptomatic clones in diploid and tetraploid potato-breeding populations. Am. J. Potato Res. 81:317-326.

28. Munro, J. 1955. The reactions of certain Solanaceous species to strains of potato virus Y. Can. J. Bot. 33:355-361.

29. Nie, X., and Singh, R. P. 2003. Specific differentiation of recombinant PVY ${ }^{\mathrm{N}: \mathrm{O}}$ and PVY ${ }^{\mathrm{NTN}}$ isolates by multiplex RT-PCR. J. Virol. Methods 113:69-77.

30. Nie, X. Z., and Singh, R. P. 2002. A new approach for the simultaneous differentiation of biological and geographical strains of Potato virus $Y$ by uniplex and multiplex RT-PCR. J. Virol. Methods 104:41-54.

31. Nie, X. Z., and Singh, R. P. 2003. Evolution of North American PVYNTN strain Tu 660 from local $\mathrm{PVY}^{\mathrm{N}}$ by mutation rather than recombination. Virus Genes 26:39-47.

32. Nie, X. Z., Singh, R. P., and Singh, M. 2004. Molecular and pathological characterization of $\mathrm{N}: \mathrm{O}$ isolates of the Potato virus $Y$ from Manitoba, Canada. Can. J. Plant Pathol. 26:573583.

33. Nolte, P., Whitworth, J. L., Thornton, M. K., and McIntosh, C. S. 2004. Efffect of seedborne Potato virus $Y$ on performance of Russet Burbank, Russet Norkotah, and Shepody potato. Plant Dis. 88:248-252.

34. Novy, R. G., Nasruddin, A., Ragsdale, D. W., and Radcliffe, E. B. 2002. Genetic Resistances to Potato leafroll virus, Potato virus $Y$, and green peach aphid in progeny of Solanum etuberosum. Am. J. Potato Res. 79:9-18.

35. Piche, L. M., Singh, R. P., Nie, X., and Gudmestad, N. C. 2004. Diversity among Potato virus $Y$ isolates obtained from potatoes grown 
in the United States. Phytopathology 94:13681375.

36. Plaisted, R. L., Halseth, D. E., Brodie, B. B., Slack, S. A., Sieczka, J. B., Christ, B. J., Paddock, K. M., and Peck, M. W. 2001. Eva: A midseason golden nematode- and virusresistant variety for use as tablestock or chipstock. Am. J. Potato Res. 78:65-68.

37. Revers, F., LeGall, O., Candresse, T., LeRomancer, M., and Dunez, J. 1996. Frequent occurrence of recombinant potyvirus isolates. $\mathrm{J}$. Gen. Virol. 77:1953-1965.

38. Singh, M., and Singh, R. P. 1994. A fastreacting bioassay for the tobacco veinal necrosis strain of potato virus $\mathrm{Y}\left(\mathrm{PVY}^{\mathrm{N}}\right)$. Plant Dis. 78:775-778.

39. Singh, R. P., McLaren, D. L., Nie, X., and Singh, M. 2003. Possible escape of a recombinant isolate of Potato virus $Y$ by serological indexing and methods of its detection. Plant Dis. 87:679-685.

40. Singh, R. P., Singh, M., and McDonald, J. G. 1998. Screening by a 3-primer PCR of North American $\mathrm{PVY}^{\mathrm{N}}$ isolates for European-type members of the tuber necrosis-inducing
PVYNTN subgroup. Can. J. Plant Pathol. 20:227-233.

41. Slack, S. A., and German, T. L. 2001. Diseases caused by viruses and viroids. Pages 57-62 in: Compendium of Potato Diseases, 2nd ed. W. R. Stevenson, R. Loria, G. D. Franc, and D. P. Weingartner, eds. American Phytopathology Society, St. Paul, MN.

42. Solomon-Blackburn, R. M., and Barker, H. 2001. A review of host major-gene resistance to potato viruses $\mathrm{X}, \mathrm{Y}, \mathrm{A}$ and $\mathrm{V}$ in potato: genes, genetics and mapped locations. Heredity 86:8-16.

43. Solomon-Blackburn, R. M., and Barker, H. 2001. Breeding virus resistant potatoes (Solanum tuberosum): a review of traditional and molecular approaches. Heredity 86:17-35.

44. Sturz, A. V., Diamond, J. F., and Stewart, J. G. 1997. Evaluation of mosaic symptom expression as an indirect measure of the incidence of $\mathrm{PVY}^{\mathrm{O}}$ in potato cv. Shepody. Can. J. Plant Pathol. 19:145-148.

45. Szemes, M., Klerks, M. M., van den Heuvel, J., and Schoen, C. D. 2002. Development of a multiplex AmpliDet RNA assay for simultane- ous detection and typing of potato virus $Y$ isolates. J. Virol. Methods 100:83-96.

46. Thornbury, D. W., Patterson, C. A., Dessens, J. T., and Pirone, T. P. 1990. Comparative sequence of the helper component (HC) region of potato virus $\mathrm{Y}$ and a HC-defective strain, potato virus C. Virology 178:573-578.

47. Valkonen, J. P. T. 1994. Natural Genes and mechanisms for resistance to viruses in cultivated and wild potato species (Solanum spp). Plant Breed. 112:1-16.

48. Valkonen, J. P. T., and Rokka, V. M. 1998. Combination and expression of two virus resistance mechanisms in interspecific somatic hybrids of potato. Plant Sci. 131:85-94

49. Valkonen, J. P. T., Slack, S. A., and Plaisted, R. L. 1994. Use of the virus-strain group concep to characterize the resistance to $\mathrm{PVX}$ and $\mathrm{PVY}^{\mathrm{O}}$ in the potato cv. Allegany. Am. Potato J. 71:507-516.

50. Walsh, K., North, J., Barker, I., and Boonham, N. 2001. Detection of different strains of Potato virus $Y$ and their mixed infections using competitive fluorescent RT-PCR. J. Virol. Methods 91:167-173. 